\title{
BEWARE OF TIGER: \\ THE LOGIC OF JUSTICE JEAN E.L. CôTÉ'S TORT LAW
}

\author{
The Honourable Justice Russell Brown* AND ANNALise ACORN** \\ PANEL MODERATOR: UBAKA OGBOGU ${ }^{* * *}$
}

\section{Remarks: The Honourable Justice RuSSEll Brown}

\section{A. INTRODUCTION}

Chief Justice Fraser, Justices, Chancellor Stollery, Dean Paton, professors, students, members of the bar, Justice Côté, and Mrs. Côté:

As a justice of the Court of Appeal of Alberta, Jean Edouard Léon Côté shaped the law of Alberta and Canada for 28 years. Armed with an articulated knowledge of the common law and a deep understanding of its method and his considerable gifts as an expositor of law to the public, to counsel, and to his and other courts, Justice Côté amassed a significant body of case law. This is a legacy that continues to inform broad swaths of our law, including our laws of commerce, the constitution, crime, contract, estates, family relations, judicial review, natural resources, and property. And of course, and as Professor Billingsley will discuss today, Justice Côté is - alongside Justice William Stevenson - the master of the civil procedure without which very little of all this legal development would matter since, as Peter Birks once pithily explained, "Procedure delivers the law." Indeed, most of what one might call Justice Côté's tort law judgments are really judgments in civil procedure. So I'm afraid the pressure to deliver this morning is really on Professor Billingsley.

Justice Côté's remarkable record of service to the law and to the Canadian people whose prosperity and freedoms it secures and protects would not, I suspect, have surprised thenjustice minister Ray Hnatyshyn when he recommended Justice Côté's appointment in 1987. In the course of preparing to make that recommendation to Cabinet, he would have learned that, from and including his time in law school, Justice Côté had been a prolific scholar and eager teacher of the law. For example — as a law student, he wrote what I still regard as the leading scholarly examination of the reception of English law in Commonwealth nations. ${ }^{2}$ As an even more pertinent example given my remarks today, 50 years ago and as a young

* Justice of the Supreme Court of Canada. For nine years, he was a professor of law (and latterly associate dean) at the University of Alberta. At the time of his appointment to the Supreme Court, he was serving on the Courts of Appeal of Alberta, the Northwest Territories, and Nunavut.

** Professor, University of Alberta. Her teaching interests lie in public international law, professional responsibility, and jurisprudence. From 2014-2015 she was a Visiting Fellow at All Souls College, Oxford. In 2009 she was an HLA Hart Fellow at the Oxford Centre for Ethics and Legal Philosophy, University College, Oxford.

*** Associate Professor, Faculties of Law and Pharmacy and Pharmaceutical Sciences, University of Alberta. He teaches Torts, Law and Medicine, Pharmacy Law and Ethics, and the Health Law Moot Program. Professor Ogbogu's research interests are in health law, public health law, science and health policy studies, law, bioethics and biomedicine, legal history of public health and health care in Canada, and the law of torts (with a special focus on medical malpractice and health care torts). Peter Birks, "Editor's Preface" in PBH Birks, ed, Pressing Problems in the Law, Volume 2: What are Law Schools For? (Oxford: Oxford University Press, 1996) at viii [emphasis added]. JE Côté, "The Introduction of English Law into Alberta" (1964) 3:2 Alta L Rev 262. 
lawyer, he wrote a comment in The Canadian Bar Review asking whether the new remoteness rule stated by the Privy Council in Wagon Mound (No. 1), ${ }^{3}$ which contradicted the longstanding rule in Re Polemis and Furness Withy \& Co. Ltd., ${ }^{4}$ that the defendant would be liable for all the direct results of negligence, whether or not foreseeable, was the proper rule to be followed in Canada as a matter of stare decisis. ${ }^{5}$ The law in Canada, he pointed out then, was "by no means clear" owing to the Supreme Court's failure to address the question squarely or clearly. "Sooner or later," he predicted, "the Supreme Court of Canada will be faced squarely with the problem," and "an early chance to have the matter finally settled would be most welcome." " And if, by "sooner or later" Justice Côté meant 39 years later when the Supreme Court pronounced in Mustapha v. Culligan of Canada Ltd., ${ }^{8}$ he was absolutely right.

To be clear, my focus on one small aspect of Justice Côté's contribution to the law — his decisions on appeals concerning tort law — reflects the limits of my expertise, not his. It is, of course, true that courts of appeal in Canada hear very few tort appeals. While many thousands of personal injury claims are brought each year across the country, only a minute handful reach trial. Fewer still are appealed. Most go nowhere or are resolved by other means, including mediation - also an interest of Justice Côté's. This does not, however, detract from the importance of a stable body of judge-made tort law; indeed, it shows its importance, because the more consistent, principled, and predictable the law, the easier the claim is to resolve without going to law (or at least to trial).

Justice Côté knew this. His judgments brim with this very insight. And I believe that insight informs what I see as several themes that emerge from those judgments: a view that the law should be logical and appeal to "common sense"; and that, while appellate courts should be mindful of the limits of their powers when it comes to reviewing trial judge's answers to questions of fact and exercises of discretion, they must see that settled law is applied, that stare decisis is maintained, and that justice according to law is done.

\section{B. The Tort LAW OF Justice Côté}

\section{LOGIC AND “COMMON SENSE”}

Justice Côté once wrote of Justice Stevenson that, "In a very partisan age, Bill's thoughts, arguments, and writing were never shaped by partisan considerations, pre-judgments, dogma, social theory, or politicized views. An important reason for that is his distrust of theory which is unrelated to experience." As the laudatory intent and tone of the statement suggests, Justice Côté shared that mistrust. But he also exhibited mistrust towards theory that was unrelated to logic. For him, Holmes' aphorism "the life of the law has not been logic: it has

Overseas Tankship (UK) Ltd v Morts Dock \& Engineering Co Ltd (The Wagon Mound), [1961] UKPC

2 [Wagon Mound (No 1)].

[1921] 3 KB 560 (CA).

JE Côté, “Is The Wagon Mound Good Law in Canada?" (1969) 47:2 Can Bar Rev 292.

Ibid at 293.

Ibid at 298-99.

2008 SCC 27.

JE Côté, “The Honourable William A. Stevenson" (1999) 37:4 Alta L Rev 847 at 847 [emphasis added]. 
been experience" 10 is partly right and partly wrong. The law was, of course, properly shaped by actual experience - otherwise, it simply wouldn't work. But for the same reason — that it had to work - it also had to be logical, in the sense that it, its reasoning, and its effects, had to be defensible according to rationality. More than once, Justice Côté described his task as an appellate reviewer as being to search for a discernible "error in logic" in the trial judge's reasons. ${ }^{11}$

The search for logical error extended to counsel's submissions. In Campbell Estate v. Calgary Power Ltd., ${ }^{12}$ the defendant Calgary Power - which had been sued by the estate of the unfortunate pilot of a plane that struck an unmarked power line that Calgary Power had erected near a private airfield - relied, inter alia, upon non-binding guidelines published by the Ministry of Transport for building airfields. That policy commented upon proximity of obstructions, suggesting that "[f]lightway approaches should be free of obstructions that exceed 1 foot in height for each 20 feet in distance from the end of the basic graded area, to a distance of 3,000 feet therefrom." ${ }^{\prime 3}$ Calgary Power's point was that it had met this guideline, since its powerline was located further from the airfield than 3,000 feet. As Justice Côté observed, however, it does not follow as a matter of logic that a policy recommending where obstacles should not exist is also a guide for when to warn of them. Continuing, he explained: "A rule forbidding wild animals as pets in the city would not let one keep such a beast in the city under a sign saying 'Beware of Tiger.' Still less would such a rule bar need for a warning sign for a fierce pet in the country." ${ }^{\prime 14}$

As avid court-watchers in Alberta will know, this was hardly the only instance in which Justice Côté put analogy to service in the cause of showing the logical fallacy of an argument. In one of his best known later judgments, Paniccia Estate v. Toal, the plaintiff (and later his estate) sued the defendant physician for having negligently misdiagnosed his incurable stomach cancer as gastritis, thereby accelerating his end of life. ${ }^{15}$ This case involved many issues - in fact, soon after the judgment was released, I added it to my syllabi for tort law and civil procedure ${ }^{16}$ — including the scope of recoverable loss under the Fatal Accidents Act, ${ }^{17}$ the use of statistical evidence in satisfying the requirement for causation, and costs, all of which Justice Côté adjudicated deftly and with an experienced hand.

But it was the part of his judgment dealing with a mitigation argument raised by the defendant that caught my eye. After his chemotherapy was discontinued in Edmonton, the plaintiff had travelled to the United States for further therapy, and his estate sought recovery of the expenses. The trial judge had granted that recovery, but the defendant argued on appeal that these expenses were not incurred in true mitigation. Just as he had not caused the

OW Holmes, Jr, The Common Law (Boston: Little, Brown \& Company, 1881) at 1.

See e.g. Campbell Estate v Calgary Power Ltd, 1988 ABCA 281 at para 10 [Campbell Estate]; see also Samson Cree Nation v O'Reilly \& Associés, 2014 ABCA 268 at para 25 [Samson Cree Nation].

Ibid.

Ibid at para 10 .

Ibid.

2012 ABCA 397 [Paniccia Estate].

Unfortunately, I never did lecture on the case, as I left the Faculty for the bench about six weeks after judgment was pronounced.

RSA 2000, c F-8. 
plaintiff's cancer, he had not prevented any possible cure, since the cancer was incurable by the time he had been consulted. There was, therefore, nothing to mitigate.

Although the plaintiff's argument was disposed of on the basis that it had not been raised at trial, Justice Côté nonetheless discussed the merits of the issue. The issue, he said, was not whether the therapies pursued in the United States were effective in mitigating the loss that the trial judge had found resulted from the defendant's negligence; rather, it was whether pursuing those therapies were reasonable attempts to mitigate that loss. ${ }^{18}$ He then conceived of the law governing recovery for mitigation of damages in a manner that I have not seen done elsewhere, but which seems to me fundamentally sound and essentially reflective of what the cases say. First, he said, "someone who is harmed or threatened by a tort ... can recover as damages the expense or detriment from reasonable attempts to mitigate that harm or threat." ${ }^{19}$ That, of course, reflected an orthodox, unremarkable account of the rule. But Justice Côté went on: " $[\mathrm{H}]$ arm caused by a tort ... includes all the expense or detriment from natural or reasonable human reactions to that harm or threat." 20

That second point is undoubtedly true, but I am unaware of it having been put in terms of "natural" human reactions to harm or threat. And still, as I say, it is indisputably sound on the case law. As Justice Côté explained, it is striking how "extremely slow" courts are "to criticize good-faith decisions by victims of torts about both whether to take steps in mitigation, or which steps, or how much expense or risk to incur in doing so." 21 One has to account, he appears to be saying, for the stakes to the claimant as the claimant would reasonably have seen them - which, in this case, would have been almost immeasurably high.

This led to discerning the "logic" of the matter, as Justice Côté saw it. The stakes were, as the defendant physician saw it, a "cure." And yes, the cancer from which the plaintiff suffered was terminal. But from the claimant's standpoint, a "cure" was not the only objective; so was slowing the inevitable progress of the cancer. Again, analogy was employed:

\footnotetext{
If a plaintiff threatened by a negligent forest fire defended himself by cutting a fire break in the forest, would he lose the right to claim the expense of that cutting because the defendant only set the fire? Would it be relevant that the defendant did not control its speed or direction, and it was inevitable that sooner or later the fire would go around the end of the fire break? And what if the time thus gained by the fire break enabled removal of some of the plaintiff's possessions to a safe place? If the attempts to mitigate need only be reasonable, why need they be exclusively devoted to mitigating one aspect of the emergency and be useless for any other? Need one design one's fire break with such legal considerations in mind? ${ }^{22}$
}

The role of logic was not confined in Justice Côté's judgments to answering the trial judge's reasons or counsel's submissions, but also extended to shaping the law itself. Although he didn't put it this way, I see the point as this: the law retains its rule on the

Paniccia Estate, supra note 15 at para 79.

Ibid at para 80 .

Ibid.

Ibid at para 86.

Ibid at paras 97-98. 
strength of its credibility, and it retains its credibility if it remains rational. If the law is an ass, the law will not be the law for long.

One of his judgments on matters of tort law particularly leaps to mind in this respect. In Ed Miller Sales \& Rentals Ltd. v. Caterpillar Tractor Co., ${ }^{23}$ the plaintiff Ed Miller dealt in parts for machines manufactured by the defendant Caterpillar. Sometimes the parts were manufactured by Caterpillar itself and sold to Ed Miller through authorized dealers, and sometimes the parts were manufactured by others. At the material time, Ed Miller bought heavily from an authorized dealer in Illinois called Peoria Tractor. Caterpillar then issued a policy directive to its authorized dealers in the United States forbidding them from selling parts to anyone outside the United States who was not an end user of those parts. Peoria Tractor ultimately complied, thereby substantially restricting Ed Miller's supply. ${ }^{24}$

Ed Miller sued Caterpillar alleging, among other things (Justice Côté described the lawsuit as "elephantine"), ${ }^{25}$ one of the economic torts — interference with contractual relations. Specifically, it alleged that Caterpillar's policy directive interfered with Ed Miller's contract with Peoria Tractor, thereby depriving Ed Miller of the benefit of Peoria Tractor's performance thereunder. This claim succeeded at trial.

In reversing the trial judge (and, I might add, in a judgment that shows his superior command of tort law and contract law), Justice Côté spotted a problem, being that Caterpillar did not initially interfere with the contract between Miller and Peoria. After Caterpillar issued its policy directive, Ed Miller and Peoria had first ignored it and continued to do business as usual, while telling Caterpillar that their contract ran to the end of that calendar year. This was a somewhat questionable representation, given that the notice provisions under that contract were unclear and indeed had been put before the trial judge. In any event, Caterpillar then relented and agreed that Peoria Tractor could continue to supply Ed Miller for that term. In other words, performance of any contract between Ed Miller and Peoria of which Caterpillar had notice had remained free from interference.

For Justice Côté, this was fatal to the economic torts claim. "The law," he said, must require that "the defendant have known there was a contract and have known its relevant terms. ${ }^{26}$ He elaborated:

Can we hold a defendant liable for interfering with the performance of a contract if he had no notice that what he did would so interfere, and had every reason to believe that it would not interfere? It would be contrary to basic principle. If a defendant knows of a contract which he reasonably believes to be irrelevant and he would not interfere with, that cannot suffice to make him liable. If knowledge is necessary, it must be relevant knowledge. $^{27}$

Continuing, he explained what he saw as the logic of this proposition. A defendant does not commit the tort if he does not interfere with the performance of the plaintiff's contract.

1996 ABCA 275, leave to appeal to SCC refused, 25594 (1 May 1997) [Ed Miller].

Ibid at paras 5-7.

Ibid at para 30 .

Ibid at para 31 [emphasis added].

Ibid at para 32 . 
It follows that, if the defendant's act does not interfere with the performance of the contract, there is no tort. Even if there is a contract whose performance would be impeded by the defendant's act, that act is not enough to result in liability if the defendant did not know of that contract. Such an outcome would, he said, be "illogical", since it would mean — again, pressing analogy into service - a purchaser could not purchase a lot from a seller who had previously contracted to sell a different lot to a third party. ${ }^{28}$ And, speaking of logic, this view of the matter - that knowledge of the contract is necessary to ground the tort - was the only explanation for a long line of authorities in Canada and England that inquired into the plaintiff's wilful blindness or recklessness, since logically, were "the defendant's knowledge that the plaintiff ... has some contract or other [to suffice], it would not be necessary to go on and speak of wilful blindness or recklessness." ${ }^{29}$

Of course, the economic torts are a bit off the beaten track when it comes to modern Canadian tort law. The tort of negligence has, over the intervening 90 years since Donoghue $v$. Stevenson, ${ }^{30}$ consumed much of the judicial attention and the law school tort law curricula. And here, too, Justice Côté's infusion of law with logic is evident.

In Bowes v. Edmonton (City of), ${ }^{31}$ the plaintiff homeowners sued the City when sections of the North Saskatchewan riverbank adjoining their homes collapsed, destroying one home and leaving the rest unsalvageable. The allegation was that the City had negligently failed to warn the homeowners at the time of applying for building permits that riverbank stability was already a demonstrated problem in this particular neighbourhood. One of the many reports said to demonstrate this problem was the " 1977 Hardy Report," prepared for the City in relation to the proposed extension of Whitemud Road, which recommended that slopes be left in their natural condition in a large area, including the area which later collapsed and on which the plaintiffs had built their homes.

The resulting judgment is well-known for its consideration of Alberta's then-new ultimate limitation period, and it is also important for its discussion of cause-in-fact and loss of a chance. But for me, the most interesting aspect of this decision is in Justice Côté's reasoning that led to the conclusion that the City of Edmonton had not fallen short of the standard of care. Significantly for Justice Côté, the trial judge had not found that the plaintiffs would not have built had the City made them aware of the Hardy Report, but rather that — had the City reconsidered that report - it would have commissioned more technical reports before deciding whether to let the plaintiffs build. But even that more modest conclusion was highly unlikely, Justice Côté thought — given the evidence that more thorough studies would have cost the City between $\$ 100,000$ and $\$ 150,000$, which, "[i]n those days ... would [have] approach[ed] the worth of a large home." 32 He then added:

In torts law, the goal is not perfection at any cost. Risk must be balanced against cost or disadvantages of the possible precaution. Precautions need not be taken which are more costly than the risk. ... It would not have been reasonable for the City to require (say) a $\$ 100,000$ study to protect a $\$ 100,000$ house, just on the ground

Ibid at para 33 .

Ibid at para 47.

[1932] UKHL 100.

2007 ABCA 347 [Bowes].

Ibid at para 62 . 
that the sum was not coming out of the City's pocket. That would not have helped the plaintiffs. Expense was a relevant and necessary factor for the City to weigh. ${ }^{33}$

Although Justice Côté had much authority on his side (which he cited ${ }^{34}$ ), he was tapping into - and firmly taking sides - on a longstanding debate, about which he would undoubtedly have been aware, regarding what it means to be the "reasonable person" as that person is understood for the purpose of assessing allegedly negligent conduct. In United States v. Carroll Towing Co., ${ }^{35}$ Justice Learned Hand defined unreasonable conduct as the failure to take precautions that would generate greater benefits in avoiding accidents than the precautions would cost — the "greater benefits" being the product of multiplying the probability of an accident occurring by the likely loss that would result. ${ }^{36}$ On the facts of that case, where an unattended barge broke away from its moorings and collided with another ship, the question of whether a reasonably careful person would have left the barge unattended would therefore be determined by comparing the cost (of attending the barge) to the risk, as determined by multiplying the likelihood of an accident and the monetized value of likely loss or injury. Were the financial burden on the defendant of attending the barge less than the probable loss arising from not attending the barge, the standard of reasonable care would be taken as having required the defendant to attend the barge. Were, however, that burden to exceed the probable outcome of not attending, a reasonable person would not take that precaution.

In McCarty v. Pheasant Run Inc., ${ }^{37}$ Justice Posner described this "Learned Hand formula" as having "greater analytical than operational significance," since "[c]onceptual as well as practical difficulties in monetizing personal injuries may continue to frustrate efforts to measure expected accident costs with the precision that is possible, in principle at least, in measuring the other side of the equation - the cost or burden of precaution." 38 But he did not doubt the formula's utility and indeed applied it in McCarty.

One sees hints of this formula at work in the canonical English case of Bolton v. Stone. ${ }^{39}$ There, the plaintiff was struck and injured by a cricket ball that had been hit from the pitch onto the adjacent lane that backed a row of houses. The probability of this occurring was extremely small - the evidence suggested it had happened as infrequently as six times in 30 years. Did (in)frequency matter? Lord Reid said that, on its own, it did. "In the crowded conditions of modern life even the most careful person cannot avoid creating some risks and accepting others." ${ }^{40}$ In this case, the risk was foreseeable — it had happened six times before, after all — but it was almost infinitesimally small. Was that enough to absolve the defendant? Not yet, cautioned Lord Reid. One has also to consider "how serious the consequences are likely to be if a person is struck." ${ }^{41}$ On balance, however, the low

Ibid [emphasis added].

Goldman v Hargrave, [1966] UKPC 12 (CA); Holbeck Hall Hotel Ltd v Scarborough Borough Council, [2000] QB 836 (CA).

159 F (2d) 169 (2nd Cir 1947).

Ibid at 173. See the discussion of this formulation of negligence by Judge Posner in McCarty v Pheasant Run Inc, 826 F (2d) 1554 at 1557 (7th Cir 1987).

Ibid.

Ibid at 1557.

[1951] UKHL 2 [Bolton].

Ibid at 7.

Ibid. 
probability of risk materializing into harm in this case weighed heavily, and the defendant was absolved of liability.

So, one side of the Learned Hand formula — probability of injury and potential magnitude of injury - were accounted for by Lord Reid. But what about the other side of the ledger that is, what of the burden on the defendant of taking precautions (by, for example, moving the cricket club into the countryside)? On this point, Lord Reid demurred: "I do not think," he said, "that it would be right to take into account the difficulty of remedial measures. If cricket cannot be played on a ground without creating a substantial risk, then it should not be played there at all." ${ }^{42}$

Fifteen years later, Lord Reid, in Wagon Mound (No. 2), ${ }^{43}$ glossed over Bolton as a case where the risk was so small that a reasonable person was justified in disregarding it. This is, to my mind, a fair reading of his speech in Bolton — or at least fairer than his accompanying point - being, that it had also been reasonable to disregard the risk in Bolton because of the considerable expense in eliminating it. Fair or not, this allowed him to distinguish Bolton from the facts of Wagon Mound (No. 2), in which oil had been discharged into a harbour due to an improperly secured fitting that only needed to be tightened. As a consequence, the Learned Hand formula could be considered in its entirety - probability of loss, magnitude of loss, and cost of precautions - because the probability of loss was slight.

Justice Côté's statement in Bowes goes further than this. It is categorical - the cost of taking care must always factor into the analysis. This is entirely consistent with his distrust of theory, since - there being no logical basis for distinguishing between cases of high risk and cases of low risk in deciding whether to consider the cost of precautions - one would then, to support drawing that distinction, have to resort to some sort of normative standpoint that may or may not be widely shared. To my knowledge, the debate has not yet been joined on the Court of Appeal of Alberta, and my present court has never considered the matter. But if and when it does, the challenge of Justice Côté - to defend any such distinction on the basis of logic — will have to be answered, conceded, or — in true Supreme Court style ignored or avoided.

\section{The Appellate Role}

As I mentioned at the outset of my remarks, Justice Côté's tort law judgments reflect more than just a view that logic should govern outcomes and legal development. He also expressed through them the view that, while appellate courts should defer to trial judges' answers to questions of fact and exercises of discretion, all deference is cast aside when it comes to questions of law. Settled law must be applied, and stare decisis must be maintained.

As to the appellate posture towards trial judgments, Justice Côté's torts judgments reveal care not to overturn trial judges simply because his own view of the evidence conflicted with the decision below or because he would have weighed the evidence differently. Even in cases where he ultimately overturned the trial decision, he was generally quite hesitant, for 
example, to reweigh expert opinion evidence, ${ }^{44}$ overturn findings of fact, ${ }^{45}$ or question the trial judge's exercise of discretion. ${ }^{46}$ As he explained in discussing the time limits for taxing the accounts at issue in Samson Cree Nation,

[c]learly the standard of appellate review is reasonableness and deference. That test is very far from being met here. If I had to, I would weigh the factors as did the Queen's Bench judge; but that is not the test. Nor is the test whether any of the appellant's views on this topic are reasonable. The test is whether the Queen's Bench judge's views and weights were unreasonable. It is impossible to say that. I cannot upset his refusal to extend time. ${ }^{47}$

Still, as we can see for example in his decision in Bowes, Justice Côté did not spare trial judgments scrutiny to discern the logic of the matter as suggested by the evidence. Nor was he one to let trial judges simply ignore expert evidence based on technical knowledge, except where “the experts' thinking or the profession or trade's practice, properly understood, must offend logic or common sense." 48

Even on questions of fact, then, Justice Côté was no meek appellate reviewer. And less so when it came to development of the law. But even here, he knew the limits of his role. He did not consider himself free, as he described it in Campbell Estate, to "debate airily what the law should be." ${ }^{49}$ If the weight of the common law was clearly against the arguments being made, he felt himself bound to apply it — as he did in Campbell Estate, and in Bowes. ${ }^{50}$ Similarly, in Sun Life Assurance Co. of Canada v. 671095 Alberta Ltd.,${ }^{51}$ in which it was argued that it was unfair to bar indemnity against a co-tortfeasor on the basis that the plaintiff could not have brought the claim itself, Justice Côté acknowledged the unfairness but explained that it was the "product of two well-settled common-law rules" 52 and that it was "too late to change those results by judge-made law." ${ }^{33}$ He was not free to amend the TortFeasors Act ${ }^{54}$ or overrule the Supreme Court of Canada or prior decisions of the Court of Appeal of Alberta in order to remove express limits on contribution. ${ }^{55}$

There is an uncommon degree of judicial humility in such decisions. Justice Côté had the deep legal knowledge and powerful writing to take up the mantle of "hero judge." But he resisted this - indeed, regularly disclaimed it in the pronouncements I have just recounted. This is not to say that he did not see present needs as having to spawn further legal development. Courts exist to develop the law, as well as to discern it and to state it. But he was mindful that, in doing so, we judges are servants of our constitution, with its separation of powers and the limits that imposes upon judicial power. He also knew that we judges come with the full gamut of human frailties, including the capacity to be terribly wrong while

See Campbell Estate, supra note 11 at para 24.

See Ed Miller, supra note 23 at paras $64,75$.

See Paniccia Estate, supra note 15 at para 157.

Samson Cree Nation, supra note 11 at para 217.

Warren v Camrose (City of), 1989 ABCA 57 at para 18, leave to appeal to SCC refused, 21450 (19

October 1989). See also Bowes, supra note 31 at paras $35,41$.

Campbell Estate, supra note 11 at para 26.

Bowes, supra note 31 at para 95.

2011 ABCA 234 [Sun Life].

Ibid at para 39 [emphasis in original].

Ibid.

RSA 2000, c T-5.

Sun Life, supra note 51 at para 42. 
having convinced ourselves that we are infallibly right. There is value both intrinsic and precious, he knew, to recognizing our limits (both personal and constitutional), to stare decisis, and to the commercial and social stability it engenders and preserves.

\section{CONCLUding REMARKS}

A reference to judicial humility is probably an apt segue to some concluding remarks about Justice Côté. Most of us are likely to have too little humility than too much. This is especially true of judges. Inside and outside of court, we are used to people deferring to us. We are accustomed to people ceasing speech when we speak. We are used to people laughing at our jokes or prefacing their answers to even our dumbest questions with the phrase "that's an excellent question." It is easy, given our human frailties and vanities, to be seduced by all this. To actually believe what people say about us and about what we say. To become proud.

Justice Côté's torts case law presents, however, an example of the important advantage that judges in the common law tradition have, should they choose to employ it, in order to avoid the problems that come with judicial pride. And that is that our role is not sufficiently discharged by merely pronouncing the law from some Delphic throne on high. We must demonstrate, by reasons, why the solution we arrive at fits within the legal order. Our legal tradition is reasoned. It is not merely a system of rules. It has to make sense, to appeal to logic - which is why Justice Côté's concern for that quality was not some mere preference; it was the means for him and other judges to avoid indulging in the prideful claim that their own idiosyncratic view of the world is the view that should prevail.

One final comment. As I read the judgments that I have recounted above, and others, I was struck by the constant concern - implicit, latent, for this was not a judge who tended to Cardozo-like ostentation - for doing justice according to law. "Justice" is, of course, served by logic and stability, but occasionally a broader notion of "justice" was at work in Justice Côté's torts case law. I have in mind his remarkable collaboration with Justice Kerans in Duncan Estate v. Baddeley. ${ }^{56}$ The issue was whether claims for loss of future earnings survive the death of the victim. Justice Kerans authored the lead judgment, holding that they do, and he gave some guidance on how to calculate such awards. The dissenting judge in that case would have held that the Legislature had, in framing the Survival of Actions Act $t^{57}$ so as to eliminate the claim of a victim "who died instantaneously ... for damages for loss of expectation of life," intended to foreclose such claims. ${ }^{58}$ Further, he doubted whether there should be substantial damages for lost earning capacity when life expectancy is shortened. The elimination of "the evil of a windfall to the estate of a victim" would be defeated by allowing claims for loss of the expectation of future income. ${ }^{59}$

In reasons concurring with Justice Kerans, Justice Côté responded to the dissent. $\mathrm{He}$ debunked the notion that because Alberta (like most if not all other jurisdictions) had 
repealed the head of damage for loss of expectation of life, it had also repealed the present head of damage. "The issue," he pointed out, "is not limited to cases of instant death" but also "to persons who are seriously injured by tortfeasors, linger for some time, and then die of their injuries." ${ }^{60}$ Nor, he added, was the issue whether damages for lost earning capacity should be allowed where substantial, even when life expectancy is shortened. In Andrews $v$. Grand \& Toy Alberta Ltd., ${ }^{61}$ the Supreme Court had made it plain, stressed Justice Côté, that there is such a head of damage. The fact that the plaintiff might die the day after judgment, or that the claim might be substantial, does not reduce his damages, nor remove his beneficiaries' right to inherit them. ${ }^{62}$ Concluding his powerful contribution to this majority effort with Justice Kerans, in which each of these great Alberta judges' intellects and passion for justice were on full display, Justice Côté said this:

\footnotetext{
Why should the tortfeasor escape scot-free if the plaintiff dies the day before judgment is pronounced? Worse still, why should the tortfeasor who has made death imminent escape scot free if he manages to drag out the litigation long enough that he produces the very death in question, before judgment?
}

In my view, the issues here transcend social utility of inheritance. They involve justice. ${ }^{63}$

I was privileged to have counted Justice Côté as a colleague, even if only for a short time. He was, and is, a true and wise scholar of the law and one of the very finest jurists I have ever known. The tort law of Justice Côté is - unavoidably, given the limits of our appellate dockets - not the product of much of his judgment-writing time, but it is obviously the product of a depth of judicial and scholarly attention that by its quality commands the judicial and scholarly attention of others. And, in its emphasis on logic and on the limits of the appellate role and the importance of stability and stare decisis, it represents, I think, a microcosm of the judicial method of a great common law judge who knew, and did, his duty. I am honoured to have been asked to reflect on it during today's proceedings, and I thank you for your kind attention.

\section{Reply: AnNAlise ACORN}

I am doubly honoured, in having both the opportunity to reflect on Justice Côté's legacy and to respond to Justice Brown's rich and insightful observations. Allow me to begin by noting that one of the hallmarks of Justice Côté's style, both as a scholar and a justice, is his abiding commitment to true human-to-human communication. With Justice Côté, one is always aware that one is being addressed as a fellow thinker. He never fails to communicate a genuine invitation to intellectual connection. The sources of this immediacy in Justice Côté's writings are many. One such source is his character. He just is a legal live wire.

Another source of this vitality, as Justice Brown has so ably pointed out, is Justice Côté's facility with fresh metaphor and apt analogy. "Beware of Tiger" is one the best of these zingers. ${ }^{64}$ I can add that, I know of more than a few prosecutors who take both delight and

Ibid at para 61

[1978] 2 SCR 229.

Duncan Estate, supra note 56 at paras 61-62.

Ibid at paras 63-64.

Campbell Estate, supra note 11 at para 10. 
solace in quoting Justice Côté's admonition in R. v. Dias, that the defense cannot demand "that the Crown 'disclose' a full list of all its unicorns."

In Justice Côté's work there is no obfuscation, no empty calories, no intellectual ostentation, no baloney. As Ralph Waldo Emerson said of Michel de Montaigne's essays, "Cut these words, and they would bleed. They are vascular and alive." ${ }^{\prime 66}$ It is a similar genius in Justice Côté that likewise animates the law. In elaborating further on how this is so, I'd like to pick up on three key elements Justice Brown has identified in Justice Côté's thinking: logic, experience, and justice according to law.

To do this, I would like to take a closer look at Justice Côté's decision in the extraordinarily complex case Ed Miller Sales \& Rentals Ltd. v. Caterpillar Tractor Co., one of the cases Justice Brown has highlighted. ${ }^{67}$ And here I would like to try to illuminate a little further the ways in which Justice Côte is an exemplar of Albert Einstein's adage: "[E]verything should be as simple as possible, but not simpler."

Let me begin, as Justice Brown has, with logic.

A spoiler alert is often required before the opening sentence of a Côté judgment. Of course, some judicial openers suggest the end result by insinuating an empathic alliance with one or other party. Think, for example, of the opening line of Lord Denning's dissent in Miller v. Jackson (a successor to Bolton): "In summertime village cricket is the delight of everyone." ${ }^{99}$ We know already whose side Denning is on. But Justice Côté does not do that. Rather, with his characteristic crispness, he simply exposes (in one opening sentence) the logical flaw in the losing party's position. ${ }^{70}$

The first sentence of Ed Miller reads as follows: "The issue here is interference with performance of a contract by one who does not know that his act will interfere." ${ }^{71}$ We know already how this highly complex lawsuit is going to end.

Let us look now at experience. As Justice Brown has explained, the plaintiff Miller argued that the defendant Caterpillar had committed the tort of interference with contractual relations between Peoria and Miller to supply parts. The first hurdle the plaintiff needed to jump, therefore, was to show that there was indeed a contract between Miller and Peoria. In rejecting the defendant's argument that there was no contract for want of consideration, Justice Côté writes: "Any suggestion that Peoria got nothing from the arrangement would

The judgment in $R v$ Dias, 2010 ABCA 382, was delivered by the Court. But it is generally assumed that since unicorns are mentioned, Justice Côté wrote it. The point that the plaintiff need not prove a negative is also made in Campbell Estate, ibid at para 19.

66 Ralph Waldo Emerson, "Montaigne; The Skeptic," in Representative Men (Boston: Phillips, Sampson \& Company, 1850), online: <https://emersoncentral.com/texts/representative-men/montaigne-theskeptic/>.

$67 \quad$ Supra note 23.

68 Alice Calaprice, The Ultimate Quotable Einstein (Princeton: Princeton University Press, 2010) at 217, 269.

69 Miller $v$ Jackson, 1977 QB 966 (CA) at 976; Bolton, supra note 39.

70 On the importance of explaining the flaw in the losing party's position, see James C Raymond, "The Architecture of Argument" (September 2004) 7 Judicial Rev: J Judicial Commission New South Wales 39.

Supra note 23 at para 1. 
startle business people. Peoria got a large valuable customer who ordered a lot and always paid on time." 72

So the contract between Miller and Peoria was made out. And in his finding of consideration, Justice Côté's resolute insistence that the law must not be an ass in the eyes of experience is clearly in evidence.

Next consider justice according to law. We have seen that the ratio in this case was that a defendant cannot be held liable for interference with a contract that they did not know existed. But how was it that Caterpillar didn't know about the contract? The reason they did not know was "Miller and Peoria agreed to tell Caterpillar that their contract ran to the end of calendar 1982. Then they did tell Caterpillar that." "73 And, as Justice Côté explains, "Caterpillar only interfered with actual supply on and after January 1, 1983."

So the plaintiff was directly responsible for the defendant not knowing about the contract. This certainly seems to affect the justice of the case. But did the plaintiff's deception make a difference to the reasoning in the case?

The answer Justice Côté gives seems to be that it might have, had the defendant pleaded estoppel. Côté writes, "Had Caterpillar pleaded estoppel, other evidence might have been led. And a new trial for that is unthinkable in this elephantine lawsuit. In any event, much the same result flows from the law of torts." ${ }^{75}$ From there on, in Côte's reasons, the plaintiff's having misinformed the defendant loses all salience. Pared down to its logical basics, it's only the defendant's lack of knowledge that matters.

Let me point out one more turn in the judgment that highlights all three points, logic, experience, and justice according to law. It was clear that after 1 January 1983, Caterpillar acted with the intention of putting Miller out of business. In all fairness, couldn't the plaintiff justly complain about that?

Again, Justice Côté puts the point with maximum logical precision. He writes, "It is not necessary here to decide whether knowledge without intent would suffice. But one must decide whether intent without knowledge would suffice." ${ }^{, 76}$ Remarkably from there, and much to my delight, Justice Côté moves into a discussion of the emotion of hatred. He writes:

In some torts or causes of action, hatred or intent to cause harm or suffering may be part of the cause of action, but this is not one of them. Indeed, some of the classic cases say that dislike of the plaintiff, or intent to cause suffering or harm to it, is neither necessary nor sufficient to give a cause of action. ${ }^{77}$ 
I do not know whether Justice Côté had been reading Aristotle's Rhetoric. But his discussion here assumes Aristotle's explanation of that emotion. ${ }^{78}$ Hatred, for Aristotle, as distinct from anger, is the desire for the non-existence of the other. As Aristotle notes, therefore, hatred, unlike anger, can be entirely bloodless and impersonal. ${ }^{79}$ Of course, acting on hatred, that is, the desire to bring about the non-existence of the other, very often constitutes, well, a hate crime. But, as Justice Côté soon points out, not so in the context of the free market! Côté writes, "What if hating a competitor and wishing that it were out of business were an alternate to any of the orthodox elements of a cause of action? Then many businesses carrying on perfectly fair competition would be guilty of economic torts to their competitors all the time." ${ }^{80}$ Acting on the desire for the non-existence of the other is not nice. But as Côté points out, in the competitive market it is not contrary to law.

That distraction disposed of, Justice Côté lands the last logical jump on a dime, again also employing vivid analogy: "[I]t is impossible to have intent without knowledge. One cannot intend to affect a nonexistent person or object, any more than an only child can love his or her brother." $" 81$

What I find admirable about Justice Côté's reasoning here is not merely that it is without reliance on policy or dogma. It is also without recourse to any unnecessary finding of fault. His logical leanness facilitates not just an economy of language but an economy of blame.

Through his detached elaboration of the law, he reveals that, in law, nothing turns on the defendant's hatred of the plaintiff or for that matter the plaintiff's deception of the defendant.

I will conclude by returning to Justice Brown's observation that Justice Côté distrusts theory divorced from logic or experience. Here, I confess, there is something ever so slightly troubling to me about the way Justice Côté uses the word "academic." When, in Campbell Estate he considers the possibility of a "mirror on the wall" that can choose the fairest among academic utopias, ${ }^{82}$ when in Samson Cree Nation, he refers to an argument as "academically interesting, at times even philosophical" we know he is not being complimentary. ${ }^{83}$ Why so negative about things academic when, by all accounts, Justice Côté is almost as renowned for his academic writings as he is for his writings from the bench?

Let me offer, well, a theory. I think legal philosopher Joseph Raz gets it exactly right when he says that the task of the academic theorist is to pay sensitive attention to reality and from there to construct conceptual frameworks to illuminate that reality. I think that when Justice Côté uses the term "academic" with disapproval he laments that all too often we scholars fail in that task. We fall prey to the tendency to what John Henry Newman in his book, The Idea of the University, termed "reckless originality." ${ }^{84} \mathrm{We}$ fail to perceive acutely

\footnotetext{
78 Aristotle, Rhetoric, translated by W Rhys Roberts (350 BCE) Book II, Part 4, online: The Internet Classics Archive <classics.mit.edu/Aristotle/rhetoric.2.ii.html>.

Ibid.

Ed Miller, supra note 23 at para 56.

Ibid at para 59.

Supra note 11 at para 30.

Ibid at para 103 .

John Henry Cardinal Newman, The Idea of a University: Defined and Illustrated (London: Longmans,
} Green \& Co, 1886) at xxi. 
and we promote our conceptual frameworks with indifference to the ways in which they obscure rather than illuminate reality and experience. We permit perception to be distorted so as to conform to our big idea. This is the sense of "academic" that, I believe, Justice Côté rightly has no time for.

In Justice Côté's convocation speech that we have just heard, he does great honour to the faculty of this university. Let us honour him in return by taking his skepticism about theory as an inspiration in our work as teachers and scholars to strive to ensure that our theories are faithfully married to both logic and experience. 
[this page is intentionally blank] 